\title{
PENGARUH PENGGUNAAN MODUL PERSONAL HYGIENE BERBASIS KEPERCAYAAN KESEHATAN (HBM) TERHADAP PERILAKUKEBERSIHAN DIRI SISWA SEKOLAH DASAR
}

\section{EFFECTIVENESS OF USE THE HYGIENE PERSONAL MODULEBASED OF HEALTH BELIEF MODEL (HBM) ON HYGIENE PERSONAL BEHAVIOR OF ELEMENTRYSCHOOL STUDENTS}

\author{
Petrus $^{1}$, Muhammad Syafar ${ }^{2}$, Andi Andahwaty ${ }^{3}$ \\ ${ }^{1}$ Bagian Promosi Kesehatan, Dinas Kesehatan Kabupaten Tana Toraja \\ ${ }^{2}$ Bagian Promosi Kesehatan, Fakultas KesehatanMasyarakat, Universitas Hasanuddin, ${ }^{3}$ Bagian \\ Manajemen Rumah Sakit, Universitas Hasanuddin Makassar
}

\begin{abstract}
Alamat Korespondensi: Petrus, SKM, Bagian Promosi Kesehatan, Dinas Kesehatan Kab. Tana Toraja, 91817 HP: 085299406788 Email: arenapetrus@ymail.com
\end{abstract}

\begin{abstract}
Abtrak
Sebagian besar siswa SD memiliki masalah personal hygiene. Penelitian ini bertujuan mengetahui pengaruh penggunaan modul personal hygiene berbasis kepercayaan kesehatan (HBM) terhadap perilaku kebersihan diri siswa. Metode penelitian adalah Quasi eksperimen dengan rancangan pretest-posttest control group design yaitu mencoba pembelajaran kebersihan diri menggunakan modul berbasis HBM kepada siswa SD yang terdiri atas 20 responden intervensi dari SDN 137 Sampean, dan 24 responden kontrol dari SDN 296 Inpres Otin. Variabel penelitian adalah pengetahuan, sikap dan tindakan kebersihan diri. Teknik sampling adalah purposive yakni kelas V SD. Analisis data menggunakan uji beda dua mean dependen dan uji beda dua mean independen dengan tingkat kepercayaan 95\%.Berdasarkan hasil uji Wilcoxon signed ranks test diketahui perbedaan pengetahuan sebelum dan sesudah perlakuan pada kelompok intervensi adalah $p=0,000$, dan perbedaan pengetahuan kelompok intervensi dan kelompok kontrol berdasarkan uji Mann Whitney sebelum perlakuan adalah $p=0,720$, dan sesudah perlakuan berdasarkan hasil uji $t$ independen adalah $p=0,000$. Adapun sikap responden sebelum dan sesudah perlakuan berdasarkan hasil uji $t$ dependen adalah $p=0,000$, dan perbedaan sikap kedua kelompok berdasarkan hasil uji $t$ independen sebelum perlakuan adalah $p=0,544$, dan setelah perlakuan menjadi $P=0,000$. Untuk tindakan sebelum dan sesudah perlakuan berdasarkan hasil uji $t$ dependen diperoleh nilai $p=0,012$, dan perbedaan tindakan kedua kelompok berdasarkan uji $t$ independen sebelum perlakuan adalah $p=0,959$, dan sesudah perlakuan diperoleh nilai $p=0,347$. Hasil penelitian menunjukkan ada pengaruh modul personal hygiene berbasis HBMterhadap pengetahuan dan sikap, tetapi tidak berpengaruh terhadap tindakan kebersihan diri siswa.
\end{abstract}

Kata kunci : Kebersihan diri, personal hygiene, modul HBM.

\begin{abstract}
Most elementary students have personal hygiene problems. This study aimed to determine the effect of the use of module-based personal hygiene health trust (HBM) on personal hygiene behavior of students. This study was conducted in SDN 137 Sampean and SDN 296 Inpres Otin. The method using in this study is quasi experimental with pretest-posttest control group design. The data were taken using a questionnaire to 20 students that learned with the module as responder intervention and 24 students who did not taught with the control module as respondents. Sampling was done by purposive the fourth grade. Data were analyzed by using a statistical analysis of two different test mean of the dependent and independent mean two different test with a confidence level of 95\%.The results showed the changes in behavior before and after the intervention group learning for knowledge before learning that the average value was 53.6 after learning the average value became 80.9 and after one month of learning passed the average value to 70.7 statistical test results obtained value of $P=0,000$. As for attitudes before learning the average value of 67.5 after learning becomes 83.5 and after one month of learning passed to 79.8, statistical test results obtained value of $P=0.000$, and for action before learning the average value of 64.2 after one month of learning passed the average value to 73.1, statistical test results obtained value of $P=0.012$.Based on the results concluded that the learning module health trust-based personal hygiene (HBM) effect on knowledge and attitudes, but does not affect the students self hygiene measures.
\end{abstract}

Keywords: Personal hygiene, HBM Module. 


\section{PENDAHULUAN}

Sebagian besar siswa SD memiliki masalah personal hygiene (kebersihan diri) , antara lain siswa yang bermasalah pada gigi (karies dan gigi berlubang) $86 \%$, siswa yang tidak menggosok gigi setiap hari $42 \%$, siswa yang tidak mencuci tangan sebelum makan $8 \%$, siswa yang tidak mencuci kaki sebelum tidur $37 \%$, siswa tidak biasa memakai alas kaki $25 \%$, siswa yang tidak biasa potong kuku $53 \%$, serta siswa yang mempunyai kebiasaan mandi 1 kali sehari $8 \%$ (Susenas, 2011). Data ini sesuai dengan hasil Riskesdas Tahun 2013 yang mencatat bahwa rumah tangga yang mempraktekkan PHBS pada tingkat nasional hanya sebesar 32,2\%. Masalah personal hygiene bisa berdampakringan seperti masalah estetika hingga menimbulkan masalah yang berat seperti diare, ISPA, dan kecacingan yang dapat membahayakan jiwa. Hasil penelitian dari Biran dkk., (2014) menemukan bahwa penyebab kematian terbesar pada anak-anak dan balita adalah diare dan ISPA.

Masalah personal hygiene adalah masalah perilaku dan pendidikan kesehatan telah terbukti dalam berbagai kasus dapat merubah perilaku. Hasil penelitian dari Raja dkk., (2016), Vangipuram (2016), Kaewpitoon (2015), Lu, C. H (2015) telah membuktikan bahwa pendidikan kesehatan yang diberikan selalu berdampak positif terhadap perubahan perilaku. Namun Glanz, (2008) mengingatkan bahwa pendidikan kesehatan akan efektif apabila didasarkan pada teori.

Salah satu bentuk pendidikan kesehatan yang dapat dilakukan untuk mengatasi masalah personal hygiene adalah pendidikan kesehatan melalui sekolah dalam program UKS. Namun hasil pengamatan yang dilakukan oleh Tim Pembina UKS Pusat menyimpulkan bahwa ternyata masih banyak sekolah yang belum melaksanakan UKS secara baik dan benar(Kemendikbud, 2014). Menurut Notoatmodjo dkk., (2012) permasalahan pelaksanaan UKS di sekolah, termasukmasalah sumber daya manusia
(SDM), terbatasnya sarana dan prasarana UKS, dankurangnya media komunikasi informasi dan edukasi (KIE). Hal ini sejalan dengan hasil penelitian Yuseran (2014) yang menyimpulkan bahwa SDM UKS belum mampu dalam memahami tugas dan fungsi UKS serta belum sanggup dalam melaksanakan tugas UKS karena tugas rangkap dan keterbatasan waktu.

Adanya masalah pelaksanaan UKS diatas, mendorong peneliti untuk meneliti penggunaan modul dalam pendidikan kesehatan di sekolah dasar mengingat fungsi modul menurut Prastowo (2012) yang menyatakan bahwa modul sebagai salah satu bentuk fungsi utama, yakni: bahan ajar mandirp̧engganti fungsi pend evaluasi, dan sebagai baha

Hasil yang diharap-

kan dari pendidikan kesehatan di sekolah adalah terwujudnya perilaku sehat siswa, baik dalam bentuk pengetahuan, sikap, maupun tindakan. Untuk mewujudkan hal terebut Glanz (2008) dan Sharma (2016) mengusulkan

penggunaan model kepercayaan kesehatan [health belief model (HBM)]dalam memberikan pendidikan kesehatan. Menurut teori HBM kemungkinan seseorang melakukan tindakan pencegahan dipengaruhi secara langsung dari dua keyakinan atau penilaian kesehatan (health beliefs), yakni ancaman cedera atau penyakit yang dirasakan dan jumlah mamfaat dan kerugian yang dirasakan(DiClemente, 2013). Hal ini sejalan dengan hasil penelitian dariVangipuram (2016) dan Kaewpitoon (2015) yang meneliti tentang efektifitas pendidikan kesehatan di sekolah dalam mengubah perilaku siswa diperoleh hasil yang positif atau signifikan baik pengetahuan, sikap, maupun perilaku.Dengan demikian tujuan penelitian ini adalah untuk mengetahui pengaruh penggunaan modul personal hygiene berbasis BHM terhadap perilaku sehat kebersihan diri siswa sekolah dasar. 


\section{BAHAN DAN METODE}

\section{Lokasi dan Rancangan penelitian}

Penelitian ini dilakukan di SDN

137 Sampean dan SDN 296 Inpres Otin.

Keduanya berada dalam wilayah kerja

Puskesmas Ge'tengan Kabupaten Tana

Toraja. Jenis penelitian adalah eksperimen semu (quasi experiment) dengan rancangan pretest-posttest control group design (Sugiyono 2016).

\section{Populasi dan sampel}

Populasi adalah seluruh siswa SDN 137 Sampean dan siswa SDN 296 Inpres Otin yang masih sementara menempuh pelajaran selama penelitian dilakukan.

Sampel sebanyak 44 orang yang dipilih secara purposive sampling yang telah memenuhi kriteria inklusi yaitu siswa kelas IV, lancar baca tulis, bersedia mengikuti penelitian $100 \%$ dengan menandatangai informed consent. Sampel dibagi menjadi dua kelompok yakni kelompok intervensi sebanyak 20 responden dari SDN 137 Sampean dan kelompok kontrol sebanyak 24 responden dari SDN 296 Inpres Otin.

\section{Metode pengumpulan data}

Proses pengumpulan data melalui beberapa tahap, tetapi secara garis besar dibagi menjadi dua tahap yakni tahap pembuatan modul dan tahap pengunaan modul sebagai bahan pembelajaran kebersihan diri.

Pada tahap pembuatan modul, proses yang dilakukan adalah penulisan modul mengikuti standar pengembangan modul dari Pusat Teknologi Informasi dan Komunikasi Pendidikan (PUSTEKKOM) Depdiknas, yang terdiri atas; perencanaan, penulisan, review, ujicoba dan revisi, finalisasi dan pencetakan(Depdiknas, 2007). Data yang dikumpulkan selama proses pembuatan modul adalah data pada waktu review dan uji coba modul. Review dan uji coba bertujuan untuk menilai kelayakan modul untuk digunakan dalam penelitian. Modul dianggap baik dan layak bila mendapat predikat baik atau sangat baik dari tim review dan terdapat peningkatan pengetahuan dan sikap responden dalam hasil uji coba di lapangan.
Pada Tahap penggunaan modul dalam penelitian data yang dikumpul antara lain; data sebelum percobaan (Pretest), data sesudah percobaan (posttest I) dan data sesudah satu bulan percobaan berlalu (postest II). Proses percobaan atau intervensi yang dilakukan yaitu 1) melakukan pretest, 2) membagikan modul kepada responden, 3) Menggunakan modul sebagai bahan pembelajaran, 4) meminta responden mengerjakan latihan soal dalam modul 5) meminta responden melanjutkan pelajaran di rumah, 6) mengevaluasi hasil belajar tahap I (Posttest I) 7) mengevaluasi hasil belajar tahap II

Data yang terkumpul selanjutnya dianalisis menggunakan bantuan program komputer SPSS terdiri atas analisis univariat (deskriptif) dan analisis bivariat (uji statistik). Dari hasil analisis dapat diketahui pengaruh penggunaan modul kebersihan diri berbasis HBM terhadap perilaku kebersihan diri siswa sekolah dasar.

\section{HASIL PENELITIAN \\ Penulisan Modul}

Tabel 1 memperlihatkan hasil penilaian modul dari tim review berdasarkan item penilaian diperoleh nilai rata-rata (mean) untuk kualitas isi 86, kualitas metode penyajian 84 , penggunaan bahasa 86 , penggunaan ilustrasi 86 , kualitas kelengkapan bahan penunjang 86 , dan kualitas fisik modul 92.

Hasil uji coba penggunaan modul yang dilaksanakan di SD Negeri No.100 Makale 3 Kelurahan Lamunan Kecamatan Makale diperoleh nilai rata-rata pengetahuan kebersihan diri siswa sebelum dilakukan pembelajaran modul (pretest) adalah 62,21 dan setelah pembelajaran (posttest) menjadi 71,30. Hasil uji statistik diperoleh nilai $\mathrm{p}=0,000$. Untuk data sikap hasilnya adalah sebelum pembelajaran modul rata-rata nilai sikap partisipan adalah 76,76 dan setelah pembelajaran berubah menjadi 80,21 , nilai $\mathrm{p}=0,000$. 


\section{Penggunaan Modul Dalam Pendidikan} Kesehatan

Tabel 1. Hasil penilaian modul oleh tim review modul.

\begin{tabular}{|c|c|c|c|c|c|c|}
\hline \multirow{3}{*}{$\begin{array}{l}\text { Aspek Yang } \\
\text { Dinilai }\end{array}$} & \multicolumn{6}{|c|}{ Skor } \\
\hline & \multicolumn{3}{|c|}{$\begin{array}{c}\text { Teman } \\
\text { Sejawat }\end{array}$} & \multirow{2}{*}{$\begin{array}{l}\text { Ahli } \\
\text { Media }\end{array}$} & \multirow{2}{*}{$\begin{array}{c}\text { Ahli } \\
\text { Materi }\end{array}$} & \multirow{2}{*}{$\begin{array}{l}\text { Rata- } \\
\text { Rata }\end{array}$} \\
\hline & 1 & 2 & 3 & & & \\
\hline Kualitas Isi & 9 & 8 & 9 & 8 & 9 & 8,6 \\
\hline Kualitas & 8 & 9 & 8 & 8 & 9 & 8,4 \\
\hline Metode & 9 & 9 & 10 & 9 & 9 & 9,2 \\
\hline Penyajian & 9 & 8 & 8 & 9 & 9 & 8,6 \\
\hline Penggunaan & 99 & 89 & 910 & 9 & 89 & $8,69,2$ \\
\hline Bahasa & & & & 9 & & \\
\hline \multicolumn{7}{|l|}{ Penggunaan } \\
\hline \multicolumn{7}{|l|}{ Ilustrasi } \\
\hline \multicolumn{7}{|l|}{ Kualitas } \\
\hline \multicolumn{7}{|l|}{ kelengkapan/ } \\
\hline \multirow{2}{*}{\multicolumn{7}{|c|}{$\begin{array}{l}\text { bahan } \\
\text { penunjang }\end{array}$}} \\
\hline & & & & & & \\
\hline \multicolumn{7}{|l|}{ Kualitas } \\
\hline fisik modul & & & & & & \\
\hline Kualitas & 8,8 & 8,5 & 9 & 8,6 & 8,8 & 8,8 \\
\hline modul secara & & & & & & \\
\hline keseluruhan & & & & & & \\
\hline
\end{tabular}

Sumber : Data Primer 2017

\section{Penggunaan Modul Dalam Pendidikan Kesehatan \\ Karakteristik responden}

Beberapa karakteristik responden dalam penelitian ini seperti pada Tabel 2 antara lain jenis kelamin responden pada kelompok intervensi lebih banyak lakilaki, yakni 55\%, sedangkan kelompok kontrol lebih banyak perempuan, yakni $66,7 \%$. Berdasarkan usia, responden dalam penelitian ini berumur 9-12 tahun dengan mayoritas berumur 9 tahun. Berdasarkan pendidikan orang tua, pendidikan ayah responden intervensi adalah SMP dan SMA masing-masing $40 \%$, sedangkan kelompok kontrol SMP $33,3 \%$ dan SMA 37,5\%. Untuk pendidikan ibu responden kelompok intervensi dominan SMA yakni 55\%, sedangkan kelompok kontrol seimbang antara SD, SMP, dan SMA masing-masing sebedar 33,3\%.

\section{Karakteristik Perilaku Kebersihan Diri Responden Pengetahuan}

Tabel 3 menunjukkan perilaku kebersihan diri responden menurut tahap penelitian. Berdasarkan hasil tersebut diketahui bahwa pengetahuan responden intervensi sebelum dan sesudah perlakuan mengalami perubahan dari pengetahuan kurang hingga sedang menjadi sedang hingga baik setelah intervensi, sedangkan pada kelompok kontrol prosentase perubahan pengetahuan tidak ada.

Tabel 4 menunjukkan rata-rata pengetahuan responden pada masingmasing tahap penelitian. Dari data tersebut terlihat bahwa pada kelompok intervensi nilai rata-rata tertinggi diperoleh pada posttest I yakni 80,81 dan yang terendah adalah nilai pretest $(53,64)$. Untuk kelompok kontrol nilai tertinggi juga diperoleh pada posttest I $(56,44)$ dan terendah pada pretest $(54,55)$.

Tabel 4 menunjukkan hasil uji statistik perbedaan dua mean independen. Untuk data pengetahuan perbedaan pengetahuan kelompok intervensi dan kelompok kontrol diperoleh dari hasil uji Mann Whitne dan uji t independen. Dari hasil uji diperoleh hasil pretest tidak ada perbedaan pengetahuan kelompok intervensi dengan kelompok kontol, pada posttest I dan posttest II diperoleh hasil signifikan perbedaan pengetahuan kelompok intervensi dengan kelompok kontrol.

Sikap

Dari data tersebut diketahui sikap responden intervensi sebelum perlakuan negatif $85 \%$ dan positif $15 \%$, setelah intervensi pada postest I diperoleh data sikap negatif $20 \%$ dan postif $80 \%$, dan pada posttest II diperoleh sikap negatif $30 \%$ dan positif $70 \%$. Sedangkan kelompok kontrol diperoleh hasil sikap negatif diatas $75 \%$ pada semua tahap penelitian. Hasil uji statistik (tabel 5) menunjukkan perbedaan sikap rata-rata kelompok intervensi dan kelompok kontrol. Dari hasil tersebut diketahui sikap kelompok intervensi sebelum perlakuan tidak berbeda dengan kelompok kontrol, tetapi setelah intervensi perbedaan menjadi signifikan. 
Tabel 2 Karakteristik responden penelitian

\begin{tabular}{|c|c|c|c|c|c|}
\hline \multirow{2}{*}{\multicolumn{2}{|c|}{ Karakteristik Responden }} & \multicolumn{2}{|c|}{ Klp. Intervensi } & \multicolumn{2}{|c|}{ Klp. Kontrol } \\
\hline & & \multirow{2}{*}{$\begin{array}{c}\text { Frek. } \\
11 \\
\end{array}$} & \multirow{2}{*}{$\begin{array}{l}\% \\
55 \\
\end{array}$} & \multirow{2}{*}{$\begin{array}{c}\text { Frek. } \\
8 \\
\end{array}$} & \multirow{2}{*}{$\begin{array}{c}\% \\
33,3 \\
\end{array}$} \\
\hline Jenis Kelamin & Laki-Laki & & & & \\
\hline & Perempuan & 9 & 45 & 16 & 66,7 \\
\hline Jumlah & & 20 & 100 & 24 & 100 \\
\hline \multirow[t]{4}{*}{ Umur (Thn) } & 9 & 12 & 60 & 11 & 45,8 \\
\hline & 10 & 5 & 25 & 9 & 35,7 \\
\hline & 11 & 2 & 10 & 3 & 12,5 \\
\hline & 12 & 1 & 5 & 1 & 4,2 \\
\hline \multicolumn{2}{|c|}{ Jumlah } & 20 & 100 & 25 & 100 \\
\hline \multirow[t]{5}{*}{ Pendidikan Ayah } & Tidak Tama SD & 1 & 5 & 0 & 0 \\
\hline & Tamat SD & 3 & 15 & 7 & 29,2 \\
\hline & Tamat SMP & 8 & 40 & 8 & 33,3 \\
\hline & Tamat SMA & 8 & 40 & 9 & 37,5 \\
\hline & Tamat PT & 0 & 0 & 0 & 0 \\
\hline \multicolumn{2}{|c|}{ Jumlah } & 20 & 100 & 25 & 100 \\
\hline \multirow[t]{5}{*}{ Pendidikan Ibu } & Tidak Tama SD & 0 & 0 & 0 & 0 \\
\hline & Tamat SD & 4 & 20 & 8 & 33,3 \\
\hline & Tamat SMP & 5 & 25 & 8 & 33,3 \\
\hline & Tamat SMA & 11 & 55 & 8 & 33,3 \\
\hline & Tamat PT & 0 & 0 & 0 & 0 \\
\hline \multicolumn{2}{|c|}{ Jumlah } & 20 & 100 & 24 & 100 \\
\hline
\end{tabular}

\section{Tabel 3. Distribusi frekuensi responden menurut perilaku kebersihan diri pada masing-masing kelompok dan tahap penelitian}

\begin{tabular}{|c|c|c|c|c|c|c|c|c|c|c|c|c|}
\hline \multirow{3}{*}{ Pengetahuan } & \multicolumn{6}{|c|}{ Kelompok Intervensi } & \multicolumn{6}{|c|}{ Kelompok Kontrol } \\
\hline & \multicolumn{2}{|c|}{ Pretest } & \multicolumn{2}{|c|}{ Posttest I } & \multicolumn{2}{|c|}{ Posttest II } & \multicolumn{2}{|c|}{ Pretest } & \multicolumn{2}{|c|}{ Posttest I } & \multicolumn{2}{|c|}{ Posttest II } \\
\hline & $\mathrm{n}$ & $\%$ & $\mathrm{n}$ & $\%$ & $\mathrm{n}$ & $\%$ & $\mathrm{n}$ & $\%$ & $\mathrm{n}$ & $\%$ & $\mathrm{n}$ & $\%$ \\
\hline Kurang & 9 & 45 & 0 & 0 & 2 & 10 & 10 & 41,7 & 10 & 41,7 & 10 & 41,7 \\
\hline Cukup & 11 & 55 & 6 & 30 & 14 & 70 & 14 & 58,3 & 13 & 54,2 & 14 & 58,3 \\
\hline Baik & 0 & 0 & 14 & 70 & 4 & 20 & 0 & 0 & 1 & 4,2 & 0 & 0 \\
\hline \multirow[t]{2}{*}{ JUMLAH } & 20 & 100 & 20 & 100 & 20 & 100 & 24 & 100 & 24 & 100 & 24 & 100 \\
\hline & \multicolumn{6}{|c|}{ Kelompok Intervensi } & \multicolumn{6}{|c|}{ Kelompok Kontrol } \\
\hline \multirow[t]{2}{*}{ Sikap } & \multicolumn{2}{|c|}{ Pretest } & \multicolumn{2}{|c|}{ Posttest I } & \multicolumn{2}{|c|}{ Posttest II } & \multicolumn{2}{|c|}{ Pretest } & \multicolumn{2}{|c|}{ Posttest I } & \multicolumn{2}{|c|}{ Posttest II } \\
\hline & $\mathrm{n}$ & $\%$ & $\mathrm{n}$ & $\%$ & $\mathrm{n}$ & $\%$ & $\mathrm{n}$ & $\%$ & $\mathrm{n}$ & $\%$ & $\mathrm{n}$ & $\%$ \\
\hline Negatif & 17 & 85 & 4 & 20 & 6 & 30 & 19 & 79,2 & 18 & 75 & 19 & 79,2 \\
\hline Positif & 3 & 15 & 16 & 80 & 14 & 70 & 5 & 20,8 & 6 & 25 & 5 & 20,8 \\
\hline \multirow[t]{2}{*}{ JUMLAH } & 20 & 100 & 20 & 100 & 20 & 100 & 24 & 100 & 24 & 100 & 24 & 100 \\
\hline & \multicolumn{6}{|c|}{ Kelompok Intervensi } & \multicolumn{6}{|c|}{ Kelompok Kontrol } \\
\hline \multirow[t]{2}{*}{ Tindakan } & \multicolumn{3}{|c|}{ Pretest } & \multicolumn{3}{|c|}{ Posttest } & \multicolumn{2}{|c|}{ Pretest } & \multicolumn{4}{|c|}{ Posttest } \\
\hline & \multicolumn{2}{|l|}{$\mathrm{n}$} & $\%$ & $\mathrm{n}$ & \multicolumn{2}{|c|}{$\%$} & $\mathrm{n}$ & $\%$ & \multicolumn{2}{|c|}{$\mathrm{n}$} & \multicolumn{2}{|l|}{$\%$} \\
\hline Buruk & \multicolumn{2}{|l|}{17} & 5 & 12 & & 0 & 19 & 79,2 & 19 & & 79,2 & \\
\hline Baik & 3 & & 5 & 8 & & 0 & 5 & 20,8 & 5 & & 20.8 & \\
\hline JUMLAH & 20 & & 0 & 20 & & 00 & 24 & 100 & 24 & & 100 & \\
\hline
\end{tabular}

Tabel 4 Nilai rata-rata pengetahuan, sikap, dan tindakan kebersihan diri responden

\begin{tabular}{lcccccc}
\hline \multicolumn{1}{c}{ MEAN } & \multicolumn{2}{c}{ KELOMPOK INTERVENSI } & \multicolumn{3}{c}{ KELOMPOK KONTROL } \\
& Pretest & Posttest I & Posttest II & Pretest & Posttest I & Posttest II \\
\hline PENGETAHUAN & 53,64 & 80,91 & 70,76 & 54,55 & 56,44 & 55,05 \\
SIKAP & 67,43 & 83,43 & 79,78 & 68,90 & 70,06 & 69,51 \\
TINDAKAN & 66,21 & $\mathrm{X}$ & 73,06 & 66,40 & $\mathrm{X}$ & 67,57 \\
\hline Ket : X X Tidak & & & &
\end{tabular}

Ket : $\mathrm{X}=$ Tidak dilakukan Pengukuran 


\section{Tindakan}

Pada tabel 3 data tindakan terlihat tindakan kebersihan diri responden intervensi sebelum perlakuan diperoleh status buruk $85 \%$, baik $15 \%$, setelah perlakuan tindakan buruk $60 \%$ dan baik $40 \%$, sedangkan kelompok kontrol diperoleh status tindakan kebersihan diri pada pretest yaitu buruk $79,2 \%$, baik $20,8 \%$, dan pada posttest prosentase tidak berubah. Rata-rata nilai tindakan responden intervensi pada pretest 66,21 dan pada posttest menjadi 73,06. Sedangkan untuk kelompok kontrol memperoleh nilai rata-rata pada pretest 66,40 dan posttest 67,57. Pada hasil uji statistik (Tabel 5) diketahui perbedaan rata-rata tindakan kelompok intervensi dengan kelompok kontrol tidak signifikan pada pretest dan posttest.

\section{PEMBAHASAN}

Dalam penelitian ini diketahui bahwa pembelajaran menggunakan modul personal hygiene berbasis HBM mempunyai pengaruh terhadap peningkatan pengetahuan dan perubahan sikap yang lebih positif terhadap perilaku kebersihan diri, namun tidak berpengaruh terhadap tindakan kebersihan diri responden.

Dari hasil penelitian diketahui
adanya peningkatan
berpengetahuan baik dari $0 \%$ pada pretest menjadi $70 \%$ pada posttest. Adanya peningkatan pengetahuan dalam penelitian ini karena pengetahuan (knowledge) adalah hasil penginderaan manusia, atau hasil tahu seseorang terhadap objek melalui indera yang dimilikinya (mata, hidung, telinga dan sebagainya)(Notoatmodjo, 2014). Modul personal hygiene berbasis HBM adalah sebuah benda berupa buku yang dijadikan objek pembelajaran yang dapat ditangkap oleh indera secara kasat mata. Selain dari bentuk bahan pembelajaran, kualitas isi juga menjadi pertimbangan. Dalam penelitian ini penilaian modul oleh tim review diperoleh nilai rata-rata 8,8 atau predikat sangat baik, dan pada hasil uji coba lapangan terbatas diperoleh hasil yang positif terhadap perubahan pengetahuan dan sikap. Hal ini berarti secara kualitas modul yang digunakan dalam penelitian dapat menimbulkan reaksi responden dalam memahami hakikat kebersihan diri. Penggunaan modul dalam pembelajaran juga didukung oleh hasil penelitian sebelumnya dari Sitmorang (2014) yang menyimpulkan bahwa pendayagunaan modul sebagai sumber belajar memiliki arti sangat penting, yaitu melengkapi dan memperkaya sumber belajar sehingga dapat meningkatkan aktivitas pembelajaran peserta didik mengikuti perkembangan teknologi yang semakin mengglobal dan hasil penelitian Septiani dkk., (2014) yang mengemukakan bahwa modul dapat memberikan hasil belajar yang lebih baik pada siswa.

Selain dari hal-hal diatas yang dapat meningkatkan pengetahuan responden, juga akibat penggunaan model HBM dalam menyusun konten modul. Konten dalam modul penelitian ini berisi ancaman dari penyakit yang digambarkan dalam bentuk narasi serta gambar-gambar terjadinya penyakit yang berhubungan dengan kebersihan diri. Dengan demikian responden akan menangkap objek pelajaran minimal oleh dua indera yakni mata sebagai indera penglihatan dan telinga sebagai indera pendengaran. Jika multi indera yang distimulasi, akan diperoleh hasil belajar yang lebih besar (Damin dkk.,2014). Modul HBM sebagai bahan pembelajaran dapat menstimulasi multiindera yakni kognitif dan motorik sehingga hasil belajar yang diperoleh lebih maksimal. Hasil penelitian ini juga sejalan dengan hasil penelitian yang dilakukan oleh Pirzade dkk.,(2012) yang menyimpulkan bahwa pendidikan yang didasarkan pada HBM dapat meningkatkan pengetahuan, persepsi kerentanan, mamfaat dan hambatan yang dirasakan pada siswa dan juga mendukung hasil penelitian Asio (2016) yang menyimpulkan ada pengaruh pelatihan menggunakan modul cara menyikat gigi terhadap pengetahuandan Tola, (2016) 
menyimpulkan bahwa intervensi

pendidikan yang didasarkan pada HBM, secara signifikan mengurangi tingkat ketidak patuhan pengobatan pada kelompok intervensi.

Pada domain sikap berdasarkan hasil penelitian diketahui ada pengaruh penggunaan modul personal hygiene berbasis HBM terhadap sikap kebersihan diri siswa sekolah dasar. Adanya pengaruh positif penggunaan modul terhadap sikap responden karena pembentukan sikap dapat dipengaruhi oleh beberapa faktor yaitu pengalaman pribadi, kebudayaan, orang lain yang dianggap penting, media massa, institusi atau lembaga pendidikan dan lembaga agama, dan faktor emosi dalam diri individu(Aswar, 1995 dalam Maulana 2014). Modul personal hygiene berbasis HBM merupakan sebuah media pembelajaran yang dapat dikategorikan sebagai media cetak, yang diberikan atau diajarkan kepada siswa dalam suatu institusi lembaga pendidikan dan diberikan oleh guru yang merupakan orang penting bagi siswa. Faktor tersebut dapat membuat responden bersikap menerima, menanggapi, menghargai dan bertanggung jawab pada pelajaran yang diberikan sebagaimana sikap seseorang dalam menanggapi sesuatu(Notoadmodjo, 2014). Selain itu, modul personal hygiene berbasis HBM yang menampilkan pilihan dikotomi ancaman penyakit (Threat Illness) bila mengabaikan kebersihan diri dan keuntungan (benefits) yang didapat bila menjaga kebersihan diri membuat responden tentunya memilih keuntungan dari pada bahaya. Hasil penelitian ini sejalan dengan penelitian Siddique dkk., (2016) meyatakan bahwa persepsi ancaman atau keyakinan akan bahaya dan efikasi diri merupakan prediktor dari tindakan pencegahan yang adekuat, dan Loke dkk., (2015) menyimpulkan bahwa persepsi keuntungan atau mamfaat yang diperoleh dan persepsi bahaya serta petunjuk perilaku merupakan prediktor perilaku.

Dari hasil penelitian ini pula diketahui bahwa tidak ada pengaruh penggunaan modul personal hygiene berbasis HBM terhadap tindakan kebersihan diri siswa sekolah dasar. Tidak adanya hasil yang signifikan ini karena tindakan atau perilaku yang nyata dipenguruhi oleh berbagai faktor. Menurut Lawrence Green (1990) dalam (Maulana 2014) untuk terjadinya sebuah perilaku atau tindakan yang diharapkan, ada tiga faktor yang menentukan atau yang perlu dipenuhi, yakni; (1) faktor predesposisi; faktor ini yang mempermudah terjadinya perilaku seseorang antara lain adalah pengetahuan, sikap, kepercayaan, keyakinan, kebiasaan, nilai-nilai, norma sosial, budaya, dan faktor sosiodemografi., (2) faktor pendorong (enabling factors), merupakan faktor yang memungkinkan terjadinya perilaku seperti lingkungan fisik, sarana yang mendukung, dan keterjangkauan atau aksesibilitas., dan (3) faktor penguat (reinforcing factor) adalah faktor yang memperkuat atau mensupport perilaku, diantaranya adalah sikap dan perilaku keluarga, orang tua, guru, petugas UKS, petugas kesehatan, dan toko masyarakat.Merujuk pada teori Lawrence green ini, maka tidak mengherankan apabila tindakan atau praktek kebersihan diri pada responden penelitian tidak signifikan karena dalam proses penelitian hanya menjangkau faktor predesposisi yaitu pengetahuan dan sikap dan tidak menjangkau atau faktor pendorong dan faktor penguat. Selain itu dalam proses pengukuran tindakan sulit untuk memantau kegiatan setiap responden, tetapi hanya mengandalkan ingatandan kejujuran dari responden hal ini sekaligus menjadi kelemahan dalam penelitian ini.

\section{KESIMPULAN DAN SARAN}

Berdasarkan hasil penelitian dan pembahasan diatas disimpulkan bahwa modul personal hygiene berbasis HBM dapat mengubah pengetahuan dan sikap, tetapi belum mampu mengubah tindakan atau praktik kebersihan diri. Oleh karena itu disarankan agar pendekatan HBM digunakan dalam pendidikan kesehatan untuk mengubah pengetahuan dan sikap 
tetapi harus ditunjang dengan aksi yang lain.

\section{DAFTAR PUSTAKA}

Asio. (2016). Pengaruh Pelatihan Menggunakan Modul Cara Menyikat Gigi. Jurnal Kesehatan Gigi Vol.03 No.1 , 21-24.

Biran, d. (2014). Effect of a behaviourchange intervention on handwashing with soap in India (SuperAmma): a clusterrandomised trial. The Lancet Global Health. 2(3), e145-e154.

Damin, S., \& Khairil. (2014). Psikologi Pendidikan (Dalam Perspektif Baru). Bandung: Alfabeta.

Depdiknas. (2007). Seri Teknologi Pembelajaran "Pengembangan Modul". Jakarta: Pusat Teknologi Informasi dan Komunikasi Pendidikan (PUSTEKKOM) Depdiknas.DiClemente, R. J., Salazar, L. F., \& Crosby, R. A. (2013). Health Behavior Teori for Public Health. Atlanta: Jones \& Bartlett Publishers.

Glanz, K., Rimer, B. K., \& Vismanath, K. (2008). Health Behavior and Health Education Theory, Research, and Practice. San Fransisco: JosseyBass.

Kaewpitoon, S., \& Kaewpitoon, N. (2015). The Effectiveness of Health Education Program On The Ophisthorchi Viverrini in Junior High School, Nakhon Ratchasima, Thailand. Antimicrobial Resistance and Infection Control , 115.

Kementrian Pendidikan dan Kebudayaan Direktorat Jenderal Pendidikan Dasar. (2014). Pedoman Pelaksanaan UKS di Sekolah. Jakarta: Kementrian Pendidikan dan Kebudayaan.

Loke, A. Y., Davies, L., \& Li, S.-f. (2015). Factors Influencing The Decision That Women Make On Their Mode of Delivery: The Health Belief Model the Health Belief Model.
BMC health services research, 15(1), 274.

Lu, C.-H., Tang, S.-T., Lei, Y.-X., Zhang, M. Q., Lin, W. Q., Ding, S. H., et al. (2015). Community-based interventions in hypertensive patients: a comparison of three health education strategies. BMC Public Health , 15-33.

Maulana, H. D. (2014). Promosi Kesehatan. Jakarta: EGC.

Notoatmodjo, S., Hassan, A., Hadi, E. N., \& Krianto, T. (2012). PROMOSI KESEHATAN DI SEKOLAH. Jakarta: Rineka Cipta.

Notoatmodjo, S. (2014) Ilmu Perilaku Kesehatan. Jakarta : Rineka Cipta.

Pirzadeh, A., \& GhR, S. (2012). Effect of Educational Program on Knowledge and Health Belief Model Structures About Acquired Immune Deficiency Syndrome (AIDS) among high school female student in Isfahan, Iran. Journal of Gorgan University of Medical Sciences, 14(3), 66-71.

Prastowo, A. (2012). Panduan Kreatif Membuat Bahan Ajar Kreatif. Yogyakarta: Diva Press.

RISKESDAS. (2013). Riset Kesehatan Dasar . Jakarta: Kementrian Kesehatan RI.

Septiani, D., Sumarni, W., \& Saptorini. (2014). Efektivitas Model Inkuiri Barbantuan Modul dalam Peningkatan Pemahaman Konsep dan Keterampilan Generik Sains. Jurnal Inovaso Pendidikan Kimia Volume 8, No.2, 1340-1350.

Sharma, M. (2016). Theoretical Foundations of Health Education and Health Promotion. Burlington: Jones \& Bartlett Publishers.

Siddiqui, T. R., Ghazal, S., Bibi, S., Ahmed, W., \& Sajjad, S. F. (2016). Use of the Health Belief Model for the Assessment of Public Knowledge and Household Preventive Practices in Karachi, Pakistan, a Dengue-Endemic City. 
PLoS Negl Trop Dis 10(11), e0005129.

Situmorang, M., \& Situmorang, A. A. (2014). Efektivitas Modul Pembelajaran Inovatif Untuk Meningkatkan Hasil Belajar Pada Pengajaran Laju Raeksi. Jurnal Penelitian Bidang Pendidikan Volume 20(2) , 139-147.

Solehati, T., Susilawati, S., Lukman, M., \& Kosasih, C. E. (2015). Pengaruh Edukasi Terhadap Pengetahuan dan Skill Guru serta Personal Hygiene Siswa SD. Kemas 11 (1), 135-143. Survei Sosial Ekonomi Nasional (Susenas). (2011). Laporan Survei Sosial Ekonomi Nasional. Jakarta: Badan Pusat Statistik.

Tola, H. H., Shojaeizadeh, D., Tol, A., Garmaroudi, G., \& Ejeta, L. T. (2016). Psychological and Educational Intervention to Improve Tuberculosis Treatment Adherence in Ethiopia Based on Health Belief Model: A Cluster
Randomized Control Trial. PloS one, 11(5), e0155147.

Vangipuran, S., Jha, A., Raju, R., \& Bashyam, M. (2016). Effectiveness of Peer Group and Conventional Method (Dentist) of Oral Health Education Programme Among 1215 year Old School Children - A Randomized Controlled Trial. Journal of Clinical and Diagnostic Research. Vol-10(5), 125-129.

Yuseran. (2014). Promosi Kesehatan Sekolah di Sekolah Dasar Kota Yogyakarta (Studi Kasus Pada Sekolah Dasar Berprestasi). Tesis . Yogyakarta: S2 Ilmu Kesehatan Masyarakat Universitas Gadjah Mada. 